\title{
Chapter 7 \\ Suitability of Peat Swamp Areas for Commercial Production of Sago Palms: The Sarawak Experience
}

\author{
Roland Yong Chiew Ming, Yusup Sobeng, Fariza Zaini, and Noraini Busri
}

\begin{abstract}
Realizing the potentials of sago as a new commodity to contribute to the Sarawak economy, the government initiated the development of sago plantations to address the shortage of raw materials in order to support the sago industry in its starch export and downstream activities. Initially the development of sago plantations was on peat, based on findings that sago can tolerate wet conditions including peat swamps. Furthermore Sarawak has the largest peat soil area in Malaysia of about 1.5 million hectares. For over the period of 15 years, it was observed that only $4 \%$ show good growth performance and these palms are mainly on shallow peat areas $(<1.5 \mathrm{~m})$, while those on very deep peat areas $(>2.5 \mathrm{~m})$ showed poor growth performance at the trunking phase as characterized by small crowns, low leaf count, stunted growth, and low succession suckers.

The Crop Research and Application Unit (CRAUN) conducted detailed studies of sago growth performance on peat to find solutions to the problems mentioned above. The study covers land preparation, prospection and selection of quality planting material, nursery management, nutritional and soil studies, cultural practices, and weed and pest control.

Based on the agronomic and cultural practices done by CRAUN for the past 10 years, it was observed that the performance of sago on peat areas $(>2.5 \mathrm{~m})$ for the first 4 years did show good growth and were on par with those palms grown on mineral soil. However, upon reaching trunking phase (4 years onward), the growth performance began to deteriorate, exhibiting distinct elemental deficiency symptoms, low leaf count, tapering trunk, and low yield.

Cost comparison on the development of sago on alluvial and peat shows a significant difference between the two soil types whereby the latter incurred high development cost and low revenue and thus contributed to the low internal rate of return (IRR). Therefore it is not economic and feasible to cultivate sago on peat. Recommendations for any new sago expansion program should focus on mineral or shallow peat soil.
\end{abstract}

R. Yong Chiew Ming $(\bowtie) \bullet Y$. Sobeng $\bullet$ F. Zaini $\bullet$ N. Busri

CRAUN Research Sdn. Bhd, Jalan Sultan Tengah, Kuching, Sarawak, Malaysia

e-mail: rldyong@yahoo.com

(C) The Author(s) 2018

H. Ehara et al. (eds.), Sago Palm, https://doi.org/10.1007/978-981-10-5269-9_7 


\subsection{Introduction}

Sago has been among the key agriculture trading commodities of Sarawak since the 1880s. Initially, sago was grown in Sarawak primarily as a smallholder crop for starch production, mainly for local food industries. Presently, although Sarawak is not the world's largest producer, it is the sole world exporter of sago starch. The export volume recorded in 2013 was 48,000 mt valued at MYR 71 million, while in 2014, it was 46,900 $\mathrm{mt}$ valued at MYR 81 million. The major export destinations are Peninsular Malaysia (60\%) and Japan (30\%), as reported by the Statistics Department, Malaysia. Nevertheless, the sago starch export volume has not increased for the past 10 years due to the low and unreliable supply of sago logs. In 1988, the State Government decided to establish sago plantations located in Mukah Division with an area of 19,063 ha, mainly in a peat area. The decision was made based on the outcome of a feasibility study. The study area comprised mainly of peat soils of the Anderson 3 series (>2 m peat depth) and observations on farmers' fields. The study recommended sago cultivation on swampy peat land with minimal water management and maintenance.

Thirteen years after plantation establishment, there were no harvestable sago palms except those planted on shallow peat areas $(<1.5 \mathrm{~m})$ which represented approximately $4 \%$ of the total plantation area. Generally, the sago palms planted on deep peat exhibited stunted growth and remained in a suppressed vegetative stage after year 5. In those palms that did have trunks, they were tapered, and the leaves had brownish necrotic leaflets. In spite of practicing an intensive and adequate fertilizer application program, none of the sago palms planted in deep peat areas of the plantation showed good growth performance.

In view of these circumstances, the Crop Research and Application Unit (CRAUN) conducted its first detailed experiment on deep peat in 2003 at the Sebakong Sago Plantation (SSP) in Mukah, Sarawak, and followed up with a subsequent experiment at the Sungai Talau Research Station (STRS) in Dalat Sarawak in 2007. The experiments covered land preparation, water management, fertilizer application, and soil studies.

\subsection{Materials and Method}

\subsubsection{Plot Establishment}

The study was conducted in Sebakong Sago Plantation and Sungai Talau Research Station with peat depth of more than $5 \mathrm{~m}$. An experimental plot was also established on mineral soil at Sungai Talau Research Station as a control plot. Besides that, observation was also made on the smallholder areas in Senau, Dalat, and in Kampung Tellian and Kampung Sesok, Mukah (Fig. 7.1). The plot preparation was in accordance with the standard practices for oil palm land clearing and water management 


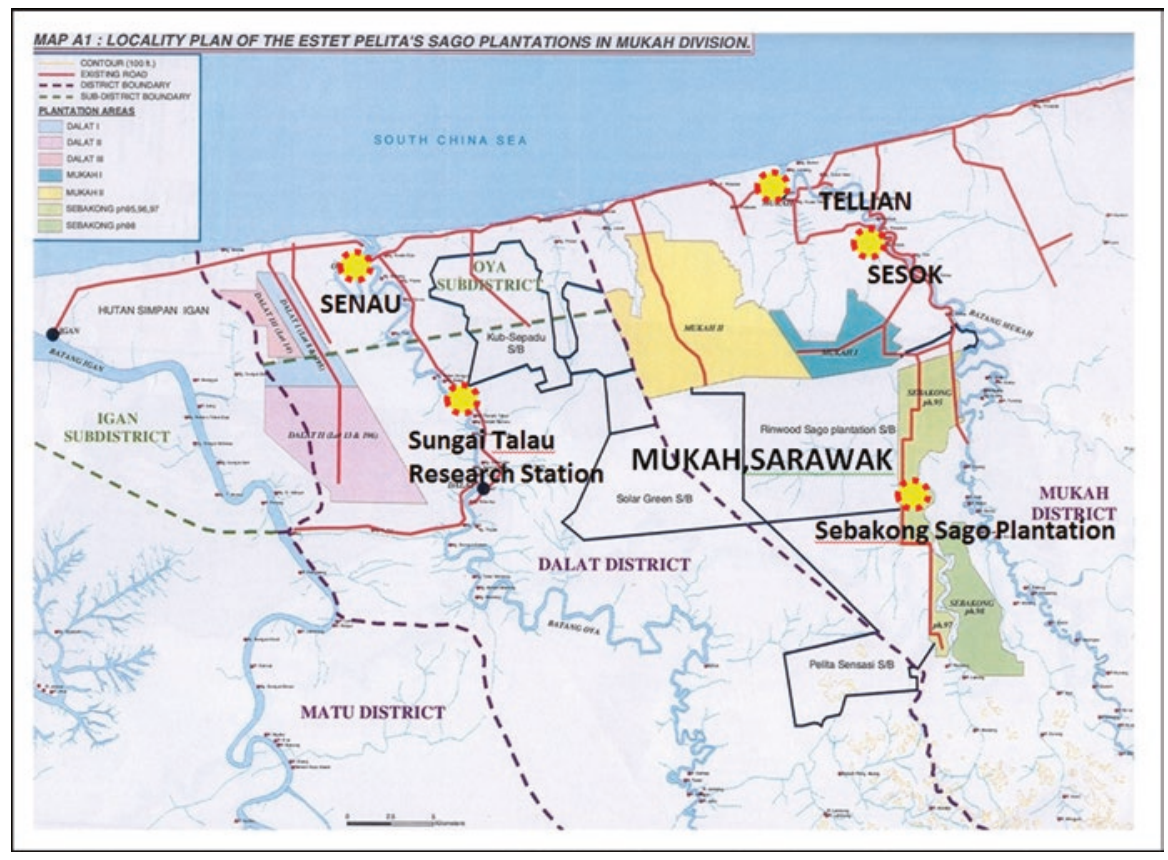

Fig. 7.1 Location of study area

on peat (Tayeb 2005) except that water table was maintained at $20-40 \mathrm{~cm}$, as compared to $50-75 \mathrm{~cm}$ for oil palm.

\subsubsection{Planting Material and Field Planting}

Selected suckers were nursed in polybags. Those with a minimum of three developed leaves and well-developed root systems were selected for field planting (Fig. 7.2). The planting density was 100 palms per hectare. The water table was maintained at $20 \mathrm{~cm}$. Lime was applied 7 days prior to planting to increase the $\mathrm{pH}$, and $200 \mathrm{~g}$ of rock phosphate fertilizer was applied during planting (Fig. 7.3).

\subsubsection{Cultural Practices and Maintenance}

Chemical weeding was done after land clearing and crop establishment to prevent regeneration of residual weeds and stop the growth of new weeds in the recently cleared areas. Planting rows were slashed followed by herbicide spraying to prevent weed competition with sago palm growth. Contact herbicide was used for the first 
Fig. 7.2 Standard polybag planting material

Fig. 7.3 Rock phosphate applied to promote root development
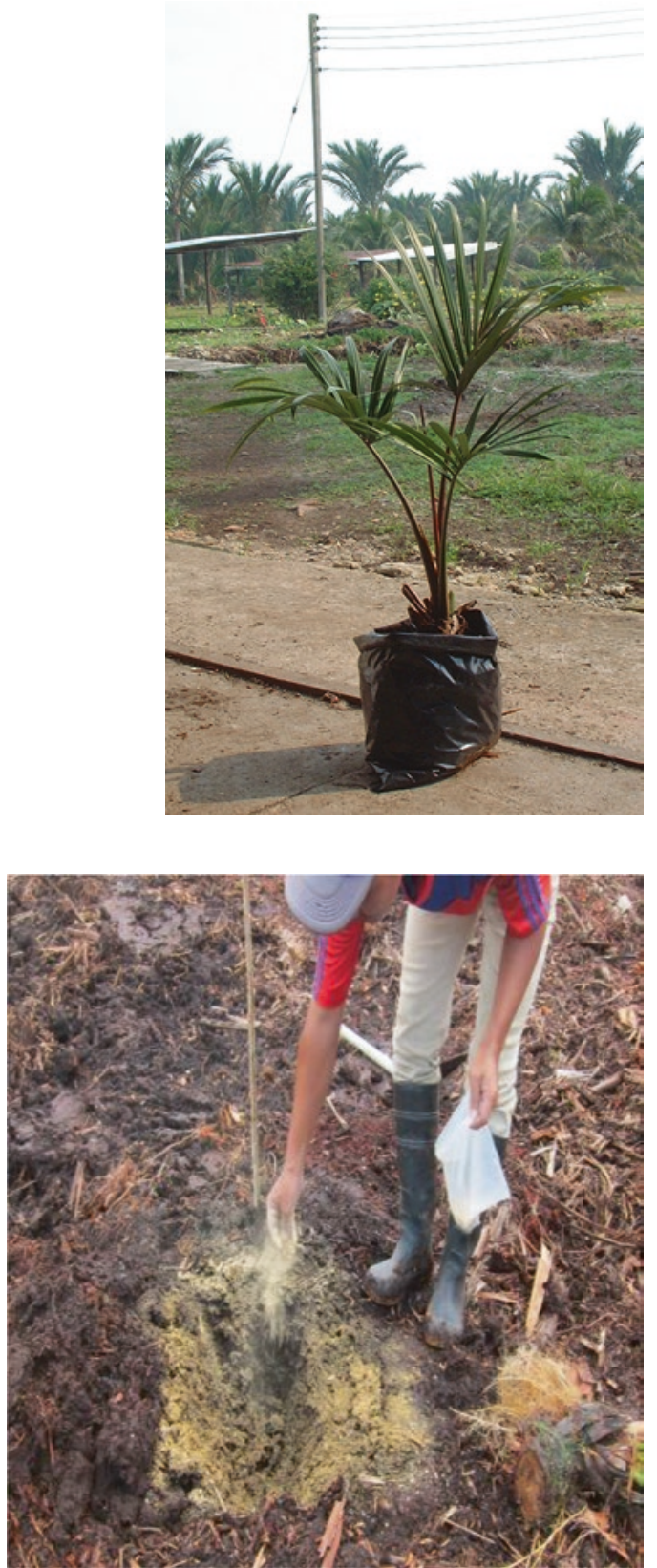

2 years after planting to reduce the risk of damage to the palms in the event of spray drift. Circular weeding was done three times per year before each fertilizer application. Weeding prevents shading out of the suckers and the choking action of creepers that can cause plant death before the crop can be well established (Yusup et al. 2007). 
Cluster maintenance is necessary to minimize the competition between mother palm and the suckers for nutrients, sunlight, and space (Peter et al. 2012). Sucker pruning is done in year 4 (Fig. 7.4). In year 4, two successional suckers are retained, followed by one successional sucker for each 18 months in the following years. This ensures sustainably harvestable palms. Dead leaves are pruned and stacked between rows to suppress weeds and to recycle the nutrients and biomass to the soil (Fig. 7.5).

Fig. 7.4 Cluster

maintenance to clear weeds
Fig. 7.5 Pruned cluster to promote trunking and damaged or dead leaves
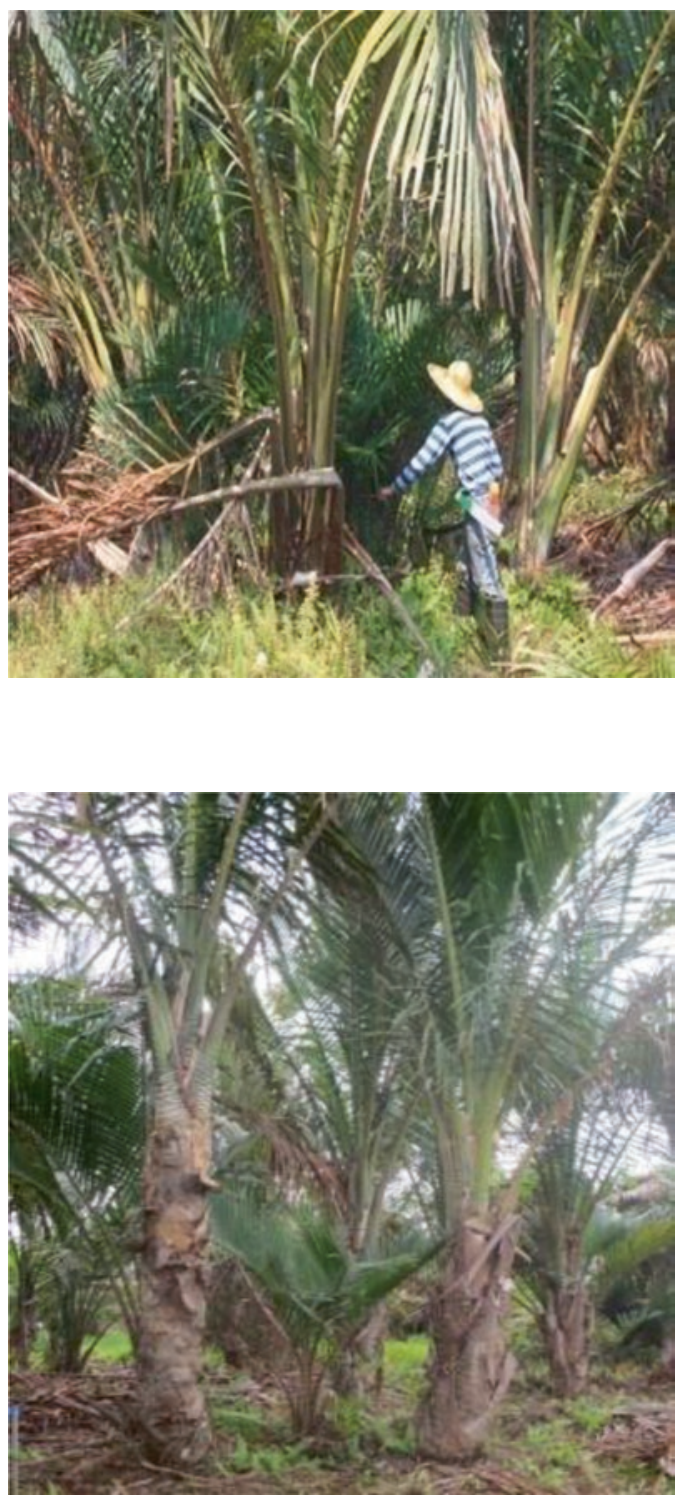
Fertilizer placement Studies using P-32

Active Root zones for 4 yrs old sago palm

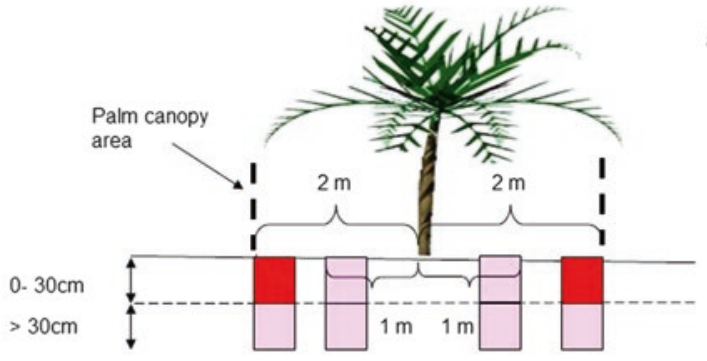

\section{Active Root Zone Area}

$0-30 \mathrm{~cm}$ depth

Most active root zone (high

density feeder roots)

$\square>30 \mathrm{~cm}$ depth

Less active root zone area (low density feeder roots)

\section{Active Root zone for 2yrs old sago palm}

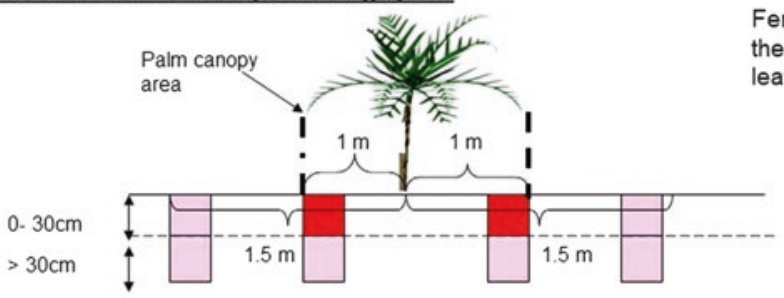

\section{Placement}

Fertilizer to be applied within the palm base to the edge of leaf canopy

Fig. 7.6 Fertilizer placement study using the P-32 isotopic method

\subsubsection{Fertilizer Application}

Fertilizer was applied around the palm base out to the edge of the leaf canopy and at the soil surface, based on the P-32 isotope dilution technique (Roland et al. 2012), as shown in Fig. 7.6.

\subsubsection{Fertilizer Trials}

Peat is a marginal soil lacking most of the important major and trace elements, namely, $\mathrm{N}, \mathrm{P}, \mathrm{K}, \mathrm{Cu}, \mathrm{Zn}$, and $\mathrm{B}$. A sago fertilizer program was initiated and formulated based on previous reports (Jong and Flach 1995) and foliar analysis (Tayeb 2005) for trials in peat areas.

The fertilizer formulated for sago is shown in Table 7.1a and 7.1b.

\subsubsection{Palm Growth Assessment Parameters}

Under optimal ecological conditions, the average number of leaves formed per year is 24 for both the rosette stage and bole formation (trunking) stage (Flach 1977). Parameters to be observed and measured for growth performance on peat are given in Table 7.2. 
Table 7.1a Fertilizer formulated for trials in the plantation (SSP)

PELITA plantation: *total amount (kg) per cluster for sago prior to first harvest (12 years)

\begin{tabular}{l|l|l|l|l|l}
\hline $\mathrm{N}$ & $\mathrm{P}$ & $\mathrm{K}$ & $\mathrm{Cu}$ & $\mathrm{B}$ & $\mathrm{Zn}$ \\
\hline 5.81 & 1.94 & 7.49 & 0.50 & 0.48 & 0.02 \\
\hline
\end{tabular}

Design: Randomized Completely Block Design $(R C B D)$ with four replications

${ }^{*}$ The total amount is apportioned according to age/stage of palm

Table 7.1b Fertilizer formulated for trials in Research Station (STRS)

\begin{tabular}{l|l|l|l|l|l|l}
\hline \multicolumn{7}{l}{ CRAUN station: *total amount (kg) per cluster before the first harvest (12 years) } \\
\hline Factorial NPK & $\mathrm{N}$ & $\mathrm{P}$ & $\mathrm{K}$ & $\mathrm{Cu}$ & $\mathrm{B}$ & $\mathrm{Zn}$ \\
\hline Level 1 & 11.6 & 3.9 & 15.0 & 0.50 & 0.48 & 0.02 \\
\hline Level 2 & 23.2 & 7.8 & 30.0 & & & \\
\hline Level 3 & 34.9 & 11.6 & 45.0 & & & \\
\hline
\end{tabular}

Design: $3 \times 3 \times 3$ factorial arranged in RCBD with three replications. Treatment: three levels of $\mathrm{N}$, $\mathrm{P}$, and $\mathrm{K}$

${ }^{*}$ The total amount is apportioned according to age/stage of palm

Table 7.2 Parameters for assessing growth performance of sago

\begin{tabular}{l|l|l|l}
\hline Number of leaves and trunking initiation year \\
\hline \multirow{2}{*}{ Status (growth performance) } & \multirow{2}{*}{ Palm stages } & $\begin{array}{l}\text { Total number of } \\
\text { leaves }\end{array}$ & $\begin{array}{l}\text { Initiation of } \\
\text { trunking year }\end{array}$ \\
\hline Good & Rosette & $>15$ & - \\
\hline Poor & & $\leq 15$ & - \\
\hline Good & \multirow{2}{*}{ Trunking } & $\geq 14$ & $<5$ years \\
\hline Poor & & $<14$ & $>5$ years \\
\hline
\end{tabular}

CRAUN (2010)

\subsubsection{Starch Yield Determination}

Starch yield determination was done for all sago palm that had reached a harvestable stage (pelawei manit). The targeted harvestable period is less than 10 years with starch yield of more than $150 \mathrm{~kg}$ per palm.

\subsubsection{Soil Studies}

The objective of this study was to determine the edaphic factors that affect sago growth on peat. The study included:

- Soil profiling for physical characterization

- Chemical analysis

- Root incursion through the soil profile 
Excavation of a soil pit was done as shown in Figs.7.7 and 7.8. Soil samples were collected from different depth horizon for nutritional analysis. The level of decomposition was determined by using the Von Post Scale which ranges from H1 (least humified) to H10 (most humified) and further grouped into three main peat types using US Department of Agriculture terminology, based mainly on their fiber content, as shown in Table 7.3 (USDA 1993).

Fig. 7.7 Excavation of soil pit (SSP, Mukah)

Fig. 7.8 An excavated soil pit (SSP, Mukah)
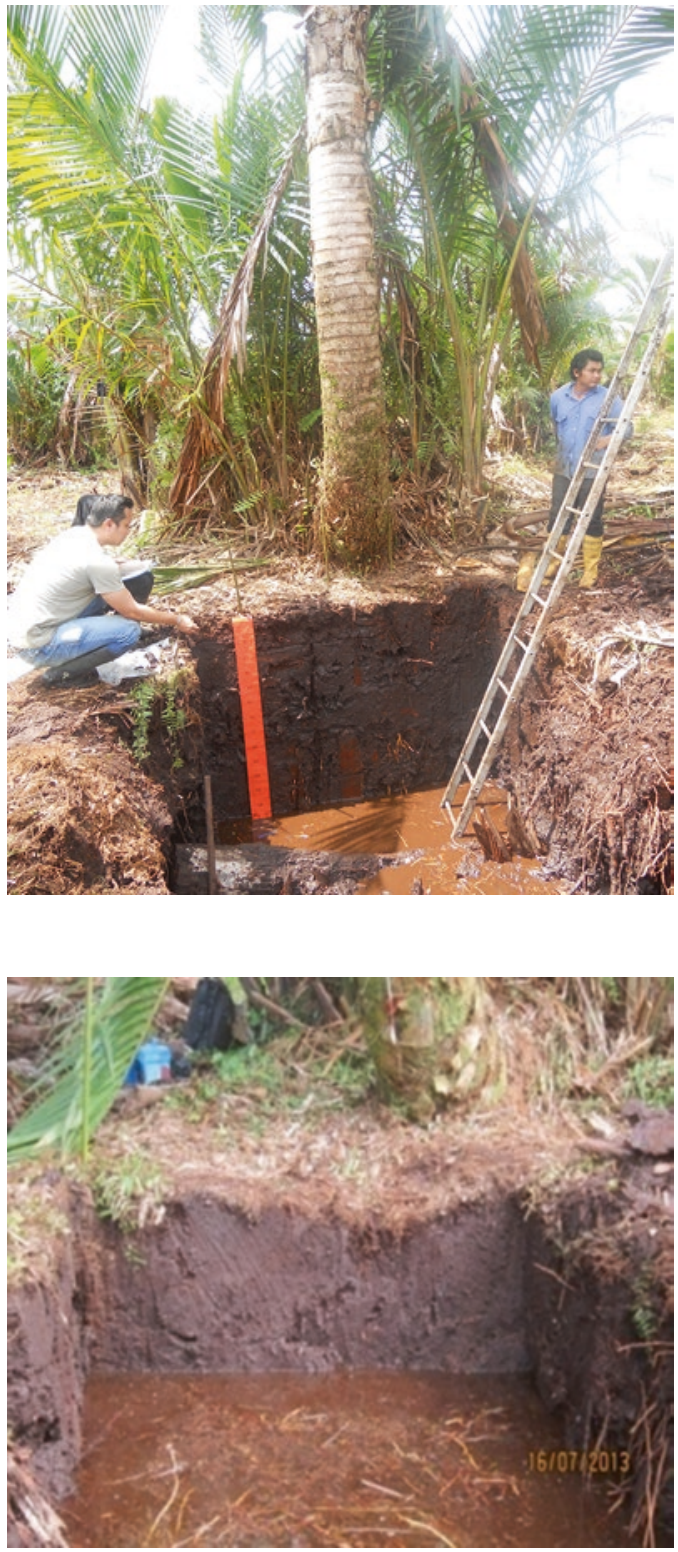
Table 7.3 An equivalent of USDA and Von Post Scale for peat humification

\begin{tabular}{l|l|l}
\hline Classification & Fiber content & Von Post class \\
\hline Fibric & $>66 \%$ & H1-H3 \\
\hline Hemic & $33-66 \%$ & H4-H6 \\
\hline Sapric & $<66 \%$ & H7-H10 \\
\hline
\end{tabular}

\subsubsection{Statistical Data Analysis}

The growth measurements and nutrient data were subjected to ANOVA using the general linear model (GLM) procedure of the Statistical Analysis Systems (SAS ${ }^{\mathrm{TM}}$ ). The least significant difference (LSD) test at $p<0.05$ was employed for the mean.

\subsection{Results and Discussions}

\subsubsection{Fertilizer Study}

Growth measurement data were taken both at the vegetative stage (1-4 years) and trunking stage ( $>5$ years) of growth. Figures 7.9 and 7.10 show the number of palm leaves under different soil types over 12 years of growth.

At the vegetative stage, the growth performance at all three locations showed good results, the number of leaves produced per palm was more than 14 (Fig. 7.9), and the highest leaf count was observed in year 2 . There were no apparent symptoms of leaf nutrient deficiency observed as the foliar analysis showed that the levels of major elements $\mathrm{N}, \mathrm{P}$, and $\mathrm{K}$ were sufficient but were not for $\mathrm{Mg}$ and trace elements for palms planted on deep peat (Tables 7.4 and 7.5).

After year 5, palm growth on deep peat started to weaken. Average number of leaves per palm dropped to less than 14 (Fig. 7.10) due to necrosis that led to rapid leaf senescence. Foliar analysis indicated that the palms were experiencing deficiencies in the major elements, $\mathrm{K}$ and $\mathrm{Mg}$ (Fig. 7.11). In addition, trace elements Mn, B, and $\mathrm{Cu}$ were also found to be deficient. These were indicated by the symptoms of retarded young spear, crinkled leaflets, and chlorotic leaves at the tips of the young leaf, respectively, as shown in Fig. 7.12. Trace elements are required in small quantities for critical enzymatic biochemical reaction to metabolize sugar and starch. Therefore, any shortfall in the availability of those elements will result in the above symptoms. Although remedial effort was done in year 5 of growth by increasing the level of insufficient major and trace elements mentioned above, there is no significant improvement on the crop growth in subsequent years. For example, K leaf nutrient concentration for sago grown on deep peat was found to be only $0.41 \%$, whereas the critical value for $\mathrm{K}$ for good growth is $0.73-0.89 \%$. When an additional $1.12 \mathrm{~kg} / \mathrm{palm}$ of $\mathrm{K}$ was added, the leaf nutrient concentration only increased to 


\section{Number of leaves at rosette stage}

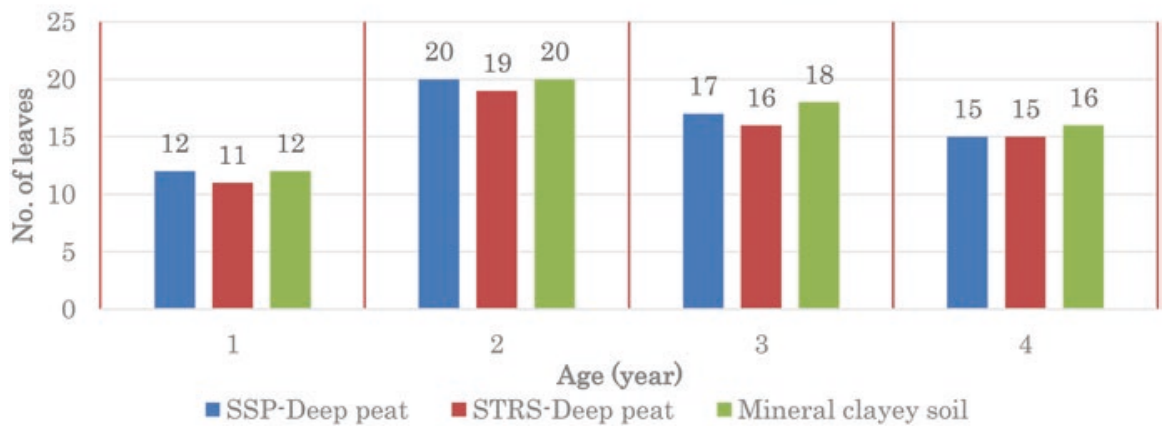

Fig. 7.9 Average number of leaves per palm at vegetative stage (1-4 years) on deep peat and mineral clayey soil

\section{Number of leaves at Trunking stage}

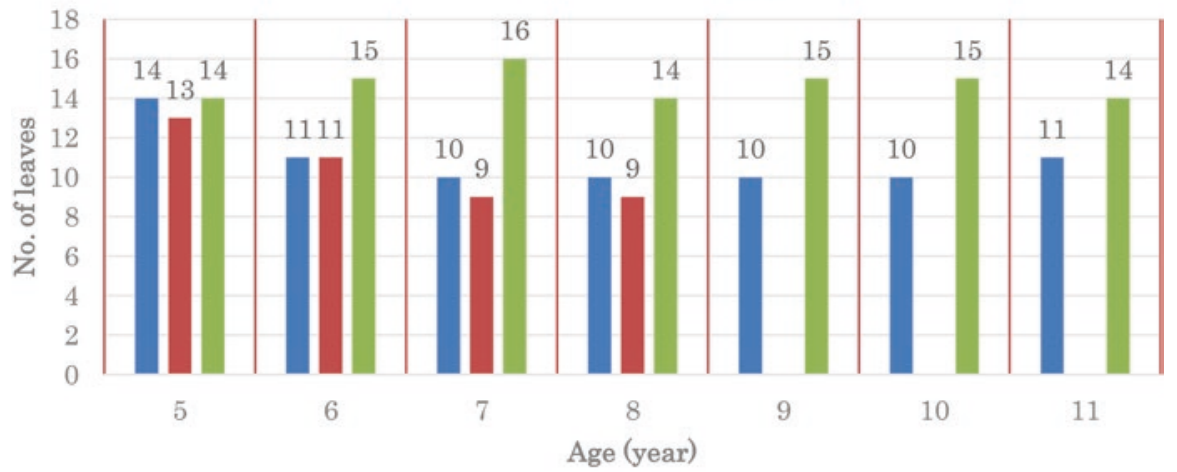

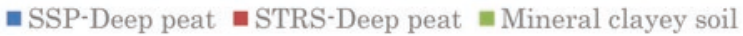

Fig. 7.10 Average number of leaves per palm at trunking stage ( $>5$ years) on deep peat and mineral clayey soil. *Leaf census at SSP-deep peat and mineral clayey soil from 5 to 11 years and STRS-deep peat from 5 to 8 years old

Table 7.4 Nutrient concentration in sago palm leaves at vegetative stages on deep peat at SSP

\begin{tabular}{|c|c|c|c|c|c|c|c|c|c|c|}
\hline \multirow[b]{2}{*}{ Palm age } & \multicolumn{5}{|l|}{$\%$} & \multicolumn{5}{|l|}{ ppm } \\
\hline & $\mathrm{N}$ & $\mathrm{P}$ & K & $\mathrm{Ca}$ & $\mathrm{Mg}$ & $\mathrm{Mn}$ & $\mathrm{Fe}$ & $\mathrm{Zn}$ & B & $\mathrm{Cu}$ \\
\hline 2 & 2.28 & 0.13 & 0.82 & 0.19 & 0.07 & 63.38 & 39.38 & 31.50 & 5.25 & 3.63 \\
\hline $\begin{array}{l}\text { a Rosette } \\
\text { stage }\end{array}$ & $\begin{array}{l}1.34- \\
1.65\end{array}$ & $\begin{array}{l}0.10- \\
0.11\end{array}$ & $\begin{array}{l}0.52- \\
0.62\end{array}$ & $\begin{array}{l}0.21- \\
0.26\end{array}$ & $\begin{array}{l}0.09- \\
0.11\end{array}$ & $\begin{array}{l}83.60- \\
249.00\end{array}$ & $\begin{array}{l}48.00 \\
79.00\end{array}$ & $\begin{array}{l}16.00- \\
21.00\end{array}$ & $\begin{array}{l}5.00- \\
9.00\end{array}$ & $\begin{array}{l}3.00- \\
8.00\end{array}$ \\
\hline 4 & 1.71 & 0.09 & 0.56 & 0.24 & 0.07 & 60.13 & 72.38 & 20.75 & 1.00 & 3.50 \\
\hline $\begin{array}{l}\text { aTrunk } \\
\text { initiation } \\
\text { stage }\end{array}$ & $\begin{array}{l}1.27- \\
1.56\end{array}$ & $\begin{array}{l}0.09- \\
0.11\end{array}$ & $\begin{array}{l}0.56- \\
0.70\end{array}$ & $\begin{array}{l}0.23- \\
0.28\end{array}$ & $\begin{array}{l}0.10- \\
0.12\end{array}$ & $\begin{array}{l}126.00- \\
248.00\end{array}$ & $\begin{array}{l}44.40- \\
57.50\end{array}$ & $\begin{array}{l}13.00- \\
19.00\end{array}$ & $\begin{array}{l}6.00- \\
11.00\end{array}$ & $\begin{array}{l}3.00- \\
11.00\end{array}$ \\
\hline
\end{tabular}

avalue of critical nutrient range of sago palm growth 
7 Suitability of Peat Swamp Areas for Commercial Production of Sago Palms...

Table 7.5 Nutrient concentration in sago palm leaves at vegetative stages on deep peat at STRS

\begin{tabular}{|c|c|c|c|c|c|c|c|c|c|c|}
\hline \multirow[b]{2}{*}{ Palm age } & \multicolumn{5}{|l|}{$\%$} & \multicolumn{5}{|l|}{ ppm } \\
\hline & $\mathrm{N}$ & $\mathrm{P}$ & K & $\mathrm{Ca}$ & $\mathrm{Mg}$ & $\mathrm{Mn}$ & $\mathrm{Fe}$ & $\mathrm{Zn}$ & B & $\mathrm{Cu}$ \\
\hline 2 & 2.05 & 0.13 & 0.72 & 0.21 & 0.09 & 202.33 & 59.00 & 14.67 & 3.67 & 2.33 \\
\hline $\begin{array}{l}\text { aRosette } \\
\text { stage }\end{array}$ & $\begin{array}{l}1.34- \\
1.65\end{array}$ & $\begin{array}{l}0.10- \\
0.11\end{array}$ & $\begin{array}{l}0.52 \\
0.62\end{array}$ & $\begin{array}{l}0.21- \\
0.26\end{array}$ & $\begin{array}{l}0.09- \\
0.11\end{array}$ & $\begin{array}{l}83.60- \\
249.00\end{array}$ & $\begin{array}{l}48.00- \\
79.00\end{array}$ & $\begin{array}{l}16.00- \\
21.00\end{array}$ & $\begin{array}{l}5.00- \\
9.00\end{array}$ & $\begin{array}{l}3.00- \\
8.00\end{array}$ \\
\hline 4 & 2.05 & 0.15 & 0.82 & 0.28 & 0.08 & 186.33 & 42.00 & 18.67 & 9.67 & 4.00 \\
\hline $\begin{array}{l}\text { aTrunk } \\
\text { initiation } \\
\text { stage }\end{array}$ & $\begin{array}{l}1.27- \\
1.56\end{array}$ & $\begin{array}{l}0.09- \\
0.11\end{array}$ & $\begin{array}{l}0.56- \\
0.70\end{array}$ & $\begin{array}{l}0.23- \\
0.28\end{array}$ & $\begin{array}{l}0.10- \\
0.12\end{array}$ & $\begin{array}{l}126.00- \\
248.00\end{array}$ & $\begin{array}{l}44.40- \\
57.50\end{array}$ & $\begin{array}{l}13.00- \\
19.00\end{array}$ & $\begin{array}{l}6.00- \\
11.00\end{array}$ & $\begin{array}{l}3.00- \\
11.00\end{array}$ \\
\hline
\end{tabular}

${ }^{a}$ Value of critical nutrient range for sago palm growth

Fig.7.11 K deficiency with symptoms of necrotic leaflets and early senescence (SSP, Mukah)

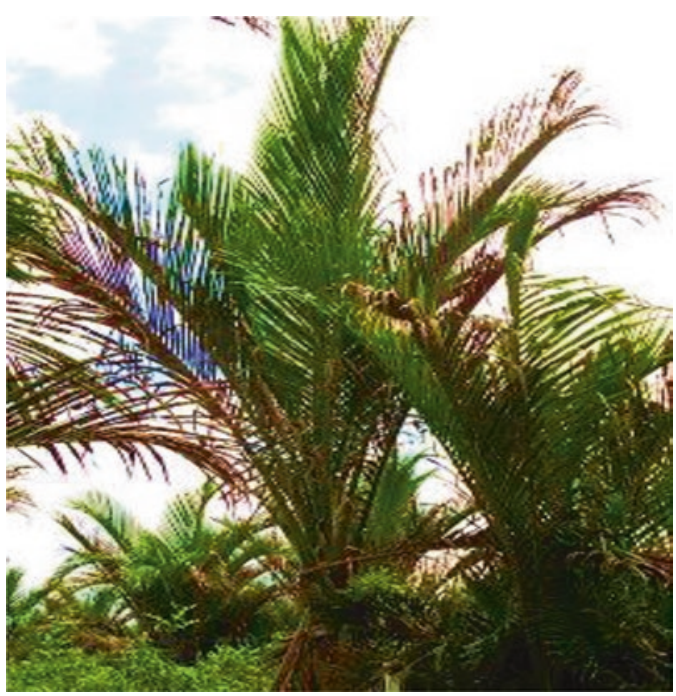

Fig. 7.12 $\mathrm{Cu}$ deficiency with symptom of leaf tip chlorosis (SSP, Mukah)

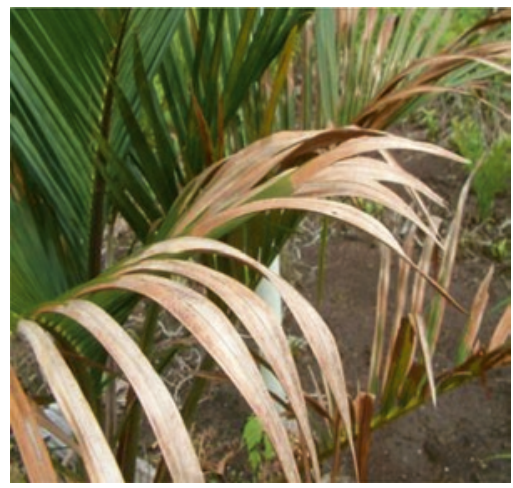


Table 7.6 Nutrient concentration in sago palm leaves at 6 years after planting on deep peat at SSP

\begin{tabular}{|c|c|c|c|c|c|c|c|c|c|c|}
\hline \multirow[b]{2}{*}{ Palm age } & \multicolumn{5}{|l|}{$\%$} & \multicolumn{5}{|l|}{ ppm } \\
\hline & $\mathrm{N}$ & $\mathrm{P}$ & $\mathrm{K}$ & $\mathrm{Ca}$ & $\mathrm{Mg}$ & $\mathrm{Mn}$ & $\mathrm{Fe}$ & $\mathrm{Zn}$ & B & $\mathrm{Cu}$ \\
\hline 6 & 1.65 & 0.09 & 0.44 & 0.23 & 0.08 & 44.92 & 35.21 & 15.08 & 3.88 & 2.71 \\
\hline $\begin{array}{l}{ }^{a} \text { Trunking } \\
\text { stage }\end{array}$ & $\begin{array}{l}1.34- \\
1.65\end{array}$ & $\begin{array}{l}0.10- \\
0.11\end{array}$ & $\begin{array}{l}0.52- \\
0.62\end{array}$ & $\begin{array}{l}0.21- \\
0.26\end{array}$ & $\begin{array}{l}0.09- \\
0.11\end{array}$ & $\begin{array}{l}83.60- \\
249.00\end{array}$ & $\begin{array}{l}48.00- \\
79.00\end{array}$ & $\begin{array}{l}16.00- \\
21.00\end{array}$ & $\begin{array}{l}5.00- \\
9.00\end{array}$ & $\begin{array}{l}3.00- \\
8.00\end{array}$ \\
\hline
\end{tabular}

${ }^{a}$ Value of critical nutrient range for sago palm growth

Table 7.7 Nutrient concentration in sago palm leaves at 6 years after planting on deep peat at STRS

\begin{tabular}{|c|c|c|c|c|c|c|c|c|c|c|}
\hline \multirow[b]{2}{*}{ Palm age } & \multicolumn{5}{|l|}{$\%$} & \multicolumn{5}{|l|}{ ppm } \\
\hline & $\mathrm{N}$ & $\mathrm{P}$ & K & $\mathrm{Ca}$ & $\mathrm{Mg}$ & $\mathrm{Mn}$ & $\mathrm{Fe}$ & $\mathrm{Zn}$ & B & $\mathrm{Cu}$ \\
\hline 6 & 2.06 & 0. & 6 & 0.28 & 0.10 & .67 & 39.67 & 19.00 & 8.67 & 4.00 \\
\hline $\begin{array}{l}{ }^{a} \text { Trunking } \\
\text { stage }\end{array}$ & $\begin{array}{l}1.34- \\
1.65\end{array}$ & $\begin{array}{l}0.10- \\
0.11\end{array}$ & $\begin{array}{l}0.52- \\
0.62\end{array}$ & $\begin{array}{l}0.21- \\
0.26\end{array}$ & $\begin{array}{l}0.09- \\
0.11\end{array}$ & $\begin{array}{l}83.60- \\
249.00\end{array}$ & $\begin{array}{l}48.00- \\
79.00\end{array}$ & $\begin{array}{l}16.00- \\
21.00\end{array}$ & $\begin{array}{l}5.00- \\
9.00\end{array}$ & $\begin{array}{l}3.00- \\
8.00\end{array}$ \\
\hline
\end{tabular}

${ }^{a}$ Value of critical nutrient range for sago palm growth

Table 7.8 Starch yield and growth parameter of sago palm on deep peat and mineral clayey soil at harvestable stage (pelawei manit)

\begin{tabular}{|c|c|c|c|c|c|}
\hline \multirow[b]{2}{*}{ Soil type } & \multicolumn{2}{|c|}{ Starch yield } & \multirow[b]{2}{*}{$\begin{array}{l}\text { Trunk length } \\
\text { (m) }\end{array}$} & \multirow[b]{2}{*}{$\begin{array}{l}\text { Average diameter } \\
(\mathrm{cm})\end{array}$} & \multirow[b]{2}{*}{$\begin{array}{l}\text { No. o } \\
\text { leaves }\end{array}$} \\
\hline & $\begin{array}{l}(\mathrm{Kg} / \\
\text { trunk })\end{array}$ & $(\mathrm{Kg} / \mathrm{m})$ & & & \\
\hline SSP-deep peat & 18.6 & 3.4 & 5.4 & 43.8 & 12 \\
\hline $\begin{array}{l}\text { Mineral clayey } \\
\text { soil }\end{array}$ & 156.7 & 16.5 & 9.5 & 56 & 18 \\
\hline
\end{tabular}

$0.44 \%$ which is still below the critical $\mathrm{K}$ value. All the deficient element results are provided in Tables 7.6 and 7.7.

A total of $80 \%$ of palms on peat were trunking, but only $36 \%$ reached a harvestable stage at year 11. Moreover, the harvestable palms recorded very low starch yield of less than $20 \mathrm{~kg} / \mathrm{palm}$ (Table 7.8). Furthermore, the growth of successional palms was also very slow. Based on the current growth, the second-generation harvesting can only be expected after 4-5 years from the first harvest (mother palm).

Whereas those palms planted on mineral clayey soil showed good growth for both mother and successional palms, the palms started reaching harvestable stage in year $9(9 \%)$ and were $100 \%$ harvestable palms by year 11 . The starch yield was also higher, more than $150 \mathrm{~kg} / \mathrm{palm}$.

Sago palm growth performance on deep peat and mineral clayey soil is shown in Fig. 7.13. 


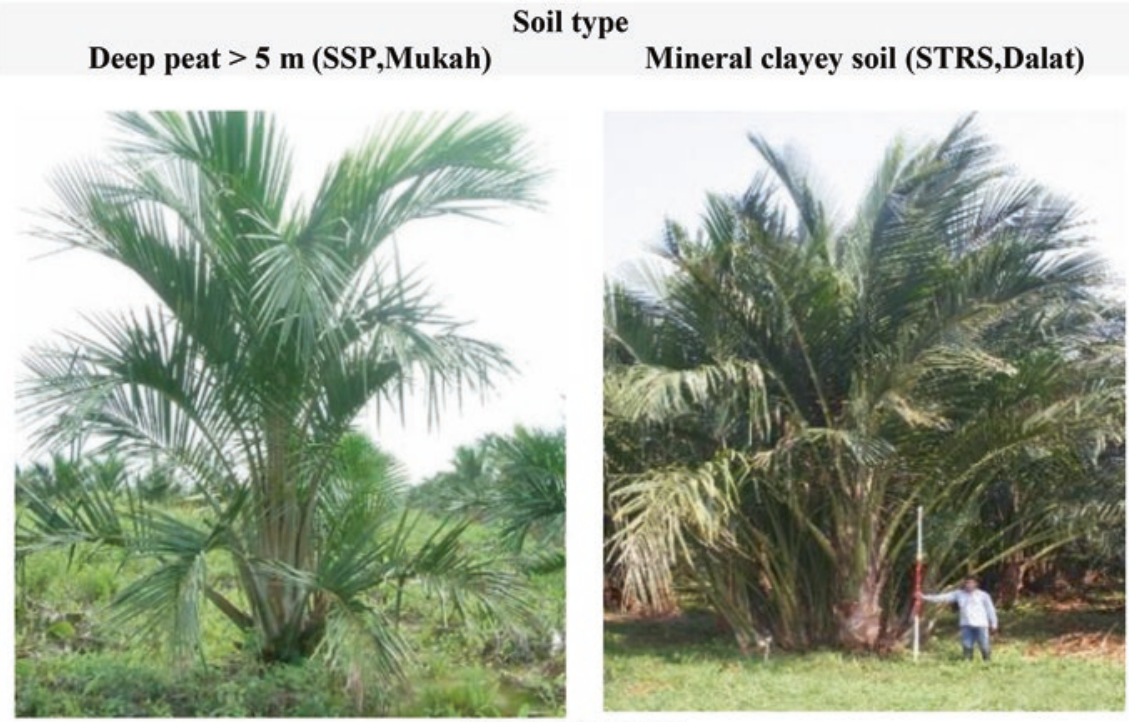

At 4 years of age
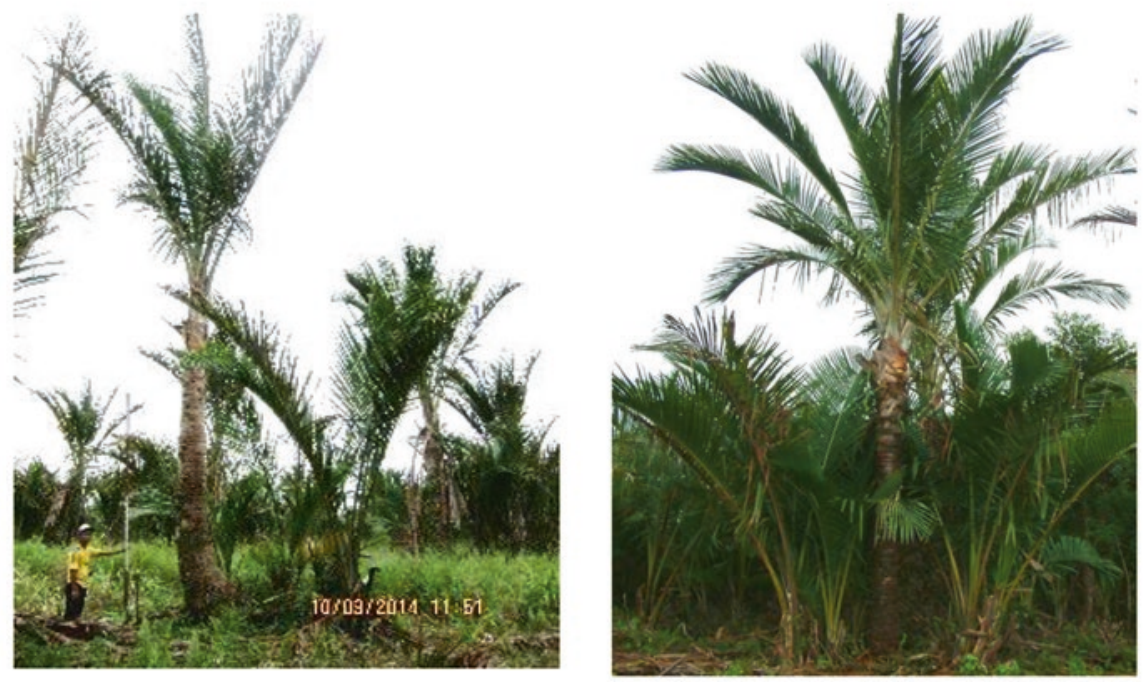

At 8 years of age

Fig. 7.13 Sago growth performance on deep peat (SSP) and mineral clayey soil (STRS) 


\subsubsection{Soil Study}

\subsubsection{Physical Properties}

In deep peat at Sebakong Sago Plantation, the top horizon, 0-20 cm, is generally highly decomposed (sapric) having a humification value of $\mathrm{H} 8$. The second horizon, which is more than $20 \mathrm{~cm}$ deep, is moderately decomposed (hemic) with a humification value of $\mathrm{H} 4$. The color change from very dark brown to dark brown, from the top horizon to second horizon, is due to the changes in the organic matter decomposition process.

The bulk density in deep peat was less than $0.15 \mathrm{~g} / \mathrm{cm}^{3}$, while in mineral soil, the bulk density is more than $1 \mathrm{~g} / \mathrm{cm}^{3}$. This was due to more than $70 \%$ of the deep peat content of undecomposed woody materials with preserved tree trunks and large roots (Fig. 7.14) compared to a low percentage of undecomposed woody materials in the mineral soil (Fig. 7.15). The undecomposed materials of deep peat areas needed a longer time to decay, and this contributed to the vacant zone where there was no growth media for sago palms. In addition, due to poor soil physical properties, root development and distribution are limited. The roots confined and limited themselves at the $50 \mathrm{~cm}$ from the soil surface which produced poor anchorage leading to poor trunking. In mineral clayey soil, the palms have better anchorage due to the underlying solid foundation that contributes to early trunking.

Fig. 7.14 Deep peat profile (SSP, Mukah)

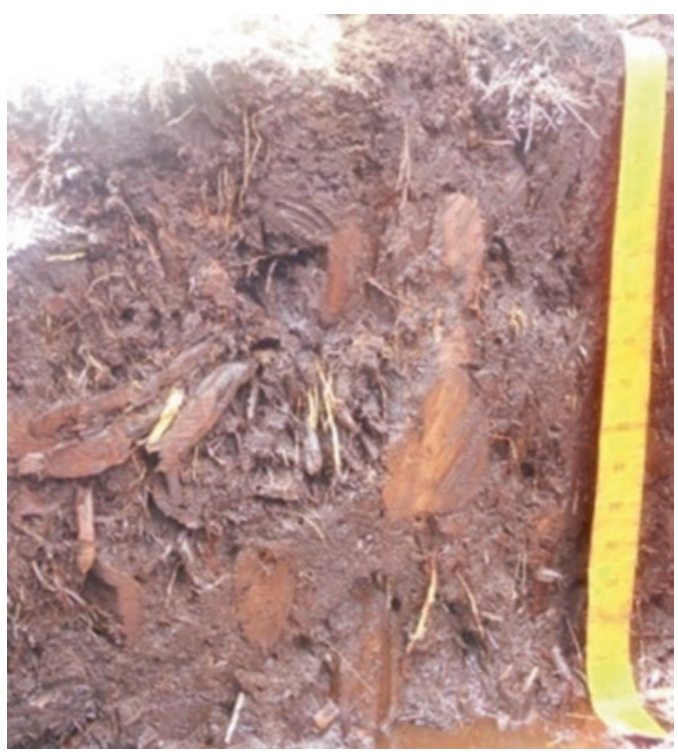


Fig. 7.15 Mineral clayey soil profile (STRS, Dalat)

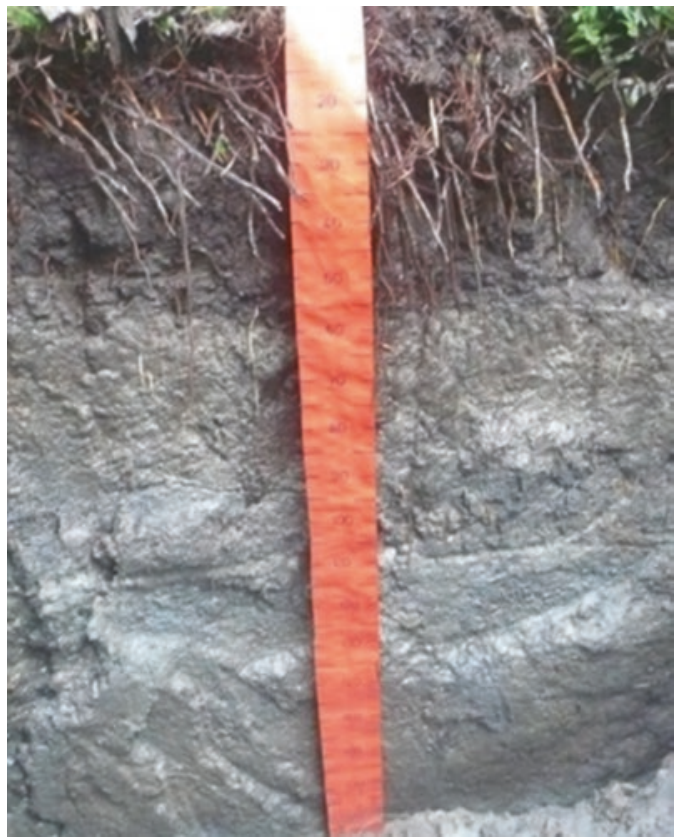

\subsubsection{Chemical Properties}

Peat soils have very low mineral content, with organic matter content reaching more than $90 \%$, and are also very acidic with a $\mathrm{pH}$ range of 3.0-4.0. Low $\mathrm{pH}$ limits the availability of major nutrients to the palms (Table 7.9). Besides this, excessive rainfall results in key nutrients, such as $\mathrm{K}, \mathrm{Mg}$, and $\mathrm{Ca}$, being washed out (leached) from the soil.

The cation exchange capacity (CEC) determines the amount of nutrients the soil can hold and that is readily available to the palms. The CEC in deep peat is very high $>70 \mathrm{meq} / 100 \mathrm{~g}$ or $70 \%$ meq which should indicate a high amount of readily available nutrients, but the high CEC is not due to the presence of cations $\mathrm{K}, \mathrm{Ca}$, or $\mathrm{Mg}$ but because of the presence of exchangeable hydrogen cations $\left(\mathrm{H}^{+}\right)$as shown by the low base saturation. Hydrogen ions are generated from organic acids during organic decay. As the soil surface is saturated with $\mathrm{H}^{+}$ions, this makes the soil unable to retain and hold other cations that will lead to nutrient leach out. In mineral soil, the CEC content is lower than in peat, but the base saturation is relatively high $(65 \%)$ compared to peat soil $(15 \%)$ which leads to nutrients in the soil being readily available to the palms. A relatively high base saturation of CEC (70-80\%) should be maintained for most cropping systems, since the base saturation determines in large measure the availability of bases for plant uptake and strongly influences soil $\mathrm{pH}$ as well (Steven 2000). 
Table 7.9 Base saturation and acidity in SSP (Deep peat) and STRS (Mineral Soil)

\begin{tabular}{|c|c|c|c|c|c|c|c|c|c|}
\hline \multirow[b]{2}{*}{ Location } & \multirow[b]{2}{*}{ Horizon } & \multirow{2}{*}{$\begin{array}{l}\text { CEC } \\
\text { (meq } \\
\%)\end{array}$} & \multicolumn{4}{|c|}{ Basic cations (meq \%) } & \multirow{2}{*}{$\begin{array}{l}\text { Base } \\
\text { saturation } \\
(\%)\end{array}$} & \multirow{2}{*}{\begin{tabular}{|l|}
$\begin{array}{l}\text { Acidic } \\
\text { cation } \\
\text { (meq \%) }\end{array}$ \\
Exch. Al \\
\end{tabular}} & \multirow[b]{2}{*}{$\begin{array}{l}\text { Acidity } \\
(\%)\end{array}$} \\
\hline & & & $\begin{array}{l}\text { Exch. } \\
\mathrm{K}\end{array}$ & $\begin{array}{l}\text { Exch. } \\
\mathrm{Ca}\end{array}$ & $\begin{array}{l}\text { Exch. } \\
\text { Mg }\end{array}$ & Total & & & \\
\hline \multirow[t]{2}{*}{ SSP1 } & $\mathrm{O}_{\mathrm{a}}$ & 84.8 & 0.29 & 12.4 & 3.39 & 16.08 & 18.96 & 0.20 & 81.04 \\
\hline & $\mathrm{O}_{\mathrm{e}}$ & 83.5 & 0.09 & 2.15 & 2.61 & 4.85 & 5.81 & 0.80 & 94.19 \\
\hline \multirow[t]{2}{*}{ SSP2 } & $\mathrm{O}_{\mathrm{a}}$ & 80.8 & 0.26 & 6.28 & 3.28 & 9.82 & 12.15 & 0.80 & 87.85 \\
\hline & $\mathrm{O}_{\mathrm{e}}$ & 82.3 & 0.14 & 1.96 & 2.79 & 4.89 & 5.94 & 1.59 & 94.06 \\
\hline \multirow[t]{3}{*}{ SSP3 } & $\mathrm{O}_{\mathrm{a}}$ & 82.7 & 0.41 & 8.47 & 3.00 & 11.88 & 14.37 & 0.20 & 85.63 \\
\hline & $\mathrm{O}_{\mathrm{a}}$ & 77.7 & 0.10 & 1.96 & 1.72 & 3.78 & 4.86 & 1.20 & 95.14 \\
\hline & $\mathrm{O}_{\mathrm{e}}$ & 79.7 & 0.08 & 1.58 & 1.85 & 3.51 & 4.40 & 2.39 & 95.60 \\
\hline \multirow[t]{4}{*}{ STRS1 } & $\mathrm{O}_{\mathrm{e}}$ & 38 & 0.17 & 1.13 & 1.92 & 3.22 & 8.47 & 8.99 & 91.53 \\
\hline & $\mathrm{O}_{\mathrm{a}}$ & 30.6 & 0.10 & 0.69 & 2.87 & 3.66 & 11.96 & 7.09 & 88.04 \\
\hline & A & 7.47 & 0.12 & 0.73 & 4.03 & 4.88 & 65.33 & 2.60 & 34.67 \\
\hline & $\mathrm{E}$ & 23.3 & 0.28 & 8.23 & 12.6 & 21.11 & 90.60 & 5.45 & 9.40 \\
\hline \multirow[t]{4}{*}{ STRS2 } & $\mathrm{O}_{\mathrm{a}}$ & 20.7 & 0.08 & 0.98 & 1.02 & 2.08 & 10.05 & 4.27 & 89.95 \\
\hline & OA & 4.97 & 0.05 & 0.37 & 0.25 & 0.67 & 13.48 & 4.27 & 86.52 \\
\hline & A & 2.07 & 0.07 & 0.46 & 1.04 & 1.57 & 75.85 & 3.75 & 24.15 \\
\hline & $\mathrm{E}$ & 6.65 & 0.14 & 1.37 & 3.70 & 5.21 & 78.35 & 3.94 & 21.65 \\
\hline
\end{tabular}

The carbon-to-nitrogen ratio $(\mathrm{C}: \mathrm{N})$ in deep peat determines the humification rate of the organic materials. The $\mathrm{C}: \mathrm{N}$ ratio on deep peat was more than 29:1 and coupled with the low $\mathrm{pH}$ resulted in low mineralization. The rate of peat deposition exceeds the rate of decomposition as most of the humification process is by anaerobic decay and the rate of metabolism is much less than the aerobic process. Most of the organic residues in these areas have a high $\mathrm{C}: \mathrm{N}$ ratio, and this requires the microbes to find additional nitrogen for the decomposition process and creates a nitrogen deficit for the palms. For example, deep peat areas mostly covered with ferns, with a high C:N ratio of 43, and tree stumps, with $\mathrm{C}: \mathrm{N}$ ratio of 560, require a long time to decay. The total $\mathrm{P}$ content of tropical peat is generally low. According to Zhang and Zhao (1997), phosphorus exists in soils in organic and inorganic form. In soils, P may exist in many different forms such as solution P, active P, and fixed P (Busman 2009).

In peat the $\mathrm{P}$ will react with humic compound to form complex formations that are easily diluted in soil solution and eventually leach out (Kim 1993). As the soil contains no clay minerals, it does not have the ability to retain the soluble phosphate being leached out. In mineral soil, high amounts of total phosphorus were due to the fixation by iron $(\mathrm{Fe})$ to form strengite $\left(\mathrm{FePO}_{4} \cdot 2 \mathrm{H}_{2} \mathrm{O}\right)$ ( $\mathrm{Kim} \mathrm{1993).}$

Potassium is generally very low in peat soil as the available $\mathrm{K}$ which was always present in the soil solution is strongly mobile and prone to leaching. The total $\mathrm{K}$ in mineral clayey was higher than deep peat due to the fixation by the negatively charged clay crystals.

The levels of trace elements in peat were very low. Total $\mathrm{Cu}, \mathrm{Zn}, \mathrm{Mn}$, and $\mathrm{Bo}$ in particular were extremely low, averaging less than $20 \mathrm{ppm}$ or $20 \mu \mathrm{g} / \mathrm{g}$ as it is taken out of the solution by forming complex formation with humid compounds. 
Table 7.10 Economic implications of sago grown on different soil types

\begin{tabular}{l|l|l|l}
\hline Soil type & Peat $>2.5 \mathrm{~m}$ & Peat $<2.5 \mathrm{~m}$ & Mineral clayey soil \\
\hline Maturity (years) & $>11$ & 10 & 9 \\
\hline Yield (tons/ha) & $<2$ & 9 & $>15$ \\
\hline Development cost (MYR/ha) & 30,800 & 26,800 & 23,600 \\
\hline Payback period (years) & - & 14 & 11 \\
\hline Sago starch production cost (MYR) & 3520 & 1020 & 700 \\
\hline Internal rate of return (IRR) & - & $13.1 \%$ & $23.4 \%$ \\
\hline
\end{tabular}

\subsubsection{Economic Evaluation}

From an economic prospective of sago development on peat and mineral soil, a comparison cost analysis was carried out. A highly significant difference was found in terms of return on investment as shown in Table 7.10

Despite providing the crop with appropriate agronomic and cultural practices, sago palms planted on peat did not respond to give better growth. It took 11 years to reach the first harvestable stage, and only $36 \%$ of the palms had starch yield of less than $20 \mathrm{~kg} /$ palm. Furthermore, the cost of development and maintenance was high which led to no return on investment.

Therefore, economically, cultivation of commercial sago plantation on peat soil seems unviable. However, on shallow peat $(<2.5 \mathrm{~m})$, it can yield about $90 \mathrm{~kg}$ per palm with $81 \%$ harvestable palms and giving a marginal internal rate of return (IRR) of $13.1 \%$, while on mineral soil, it could yield more than $150 \mathrm{~kg}$ per palm giving an IRR of $23.4 \%$.

\subsection{Conclusion and Recommendation}

All study plots for both peat and mineral soil showed good vegetative growth in the first 4 years. However, the growth started to decline on peat areas after year 5, while on the mineral soil, it continues to grow well. The leaf number started to decline. Only $36 \%$ reached harvestable stage at year 11 when grown on peat, whereas those palms planted on mineral clayey soil reached $100 \%$ harvestable stage by year 11 . In fact the first harvest of $9 \%$ of the palms in mineral clayey soil can be done at year 9 . The harvestable palms in peat areas had a low starch yield of less than $20 \mathrm{~kg} / \mathrm{palm}$, while the harvestable palms on mineral soil had a starch yield of more than $150 \mathrm{~kg} / \mathrm{palm}$.

Thus, the studies showed that the number of harvestable palm and starch yield on peat area after 12 years of planting is lower than that of mineral clayey soil. Therefore, planting sago on peat is not feasible. Based on the economic evaluation, sago on peat with the yield of less than $20 \mathrm{~kg}$ per palm does not give any return on investment. To be viable, the harvestable age must be less than 10 years with the yield of $150 \mathrm{~kg}$ per palm which will give an IRR of $23 \%$ (as compared to $21 \%$ for oil palm). This IRR of $23 \%$ can be achieved if palms are planted on mineral soil. 
Last but not least, the cost of development and maintenance on peat is comparatively higher and tends to affect the environment adversely if not managed properly.

Acknowledgments We acknowledge the Government of Sarawak; Land Custody and Development Authority (LCDA); Pelita Mukah Sebakong Sago Plantation (PMSSP); Malaysia Nuclear Agency; Dr. Mohd. Tayeb Dolmat, former MPOB agronomist; and the staff of CRAUN at Sungai Talau Research Station for their support and success of this project.

\section{References}

Busman L (2009) The nature of phosphorus in soils. University of Minnesota, St Paul

CRAUN (2010) Monitoring and evaluation on sago growth performance in the plantations. CRAUN Research Sdn. Bhd, Sarawak

Flach M (1977) Sago palm (Metroxylon sagu Rottb.) promoting the conservation and use of underutilized and neglected crops. 13. Institute of Plant Genetics and Crop Plant Research, Rome

Jong FS (1995) Research for the development of sago palm (Metroxylon sagu Rottb.) cultivation in Sarawak, Malaysia. PhD thesis, Wageningen Agricultural University, Netherlands

Kim HT (1993) Principles of soil chemistry, 2nd edn. Marcel Dekker Inc., New York

Peter SH, Noraini B, Yusup S (2012) Effect of selective sucker pruning of sago (Metroxylon sagu) four years field performance. 2nd Asean Sago Symposium proceeding, UNIMAS Sarawak Malaysia

Roland YCM, Noraini B, Ahamad SM, Khairuddin AR (2012) Fertilizer placement study using P isotopic tracer technique on sago palms. In: 2nd Asean Sago symposium proceeding, UNIMAS Sarawak Malaysia

Steven CH (2000) Soil fertility basics. Soil science extension. North Carolina State University, Raleigh

Tayeb MD (2005) Technologies for planting oil palm on peat. Malaysian Palm Oil Board, Kuala Lumpur

USDA (1993) Soil survey manual. Soil Survey Division, USDA, Washington, DC

Yusup S, Edwin LCL, Noraini B, Ahmad Zaki H (2007) Manual for planting and maintenance of sago plantation on peat. CRAUN Research Sdn. Bhd, Sarawak

Zhang J, Zhao B (1997) Phosphorus dynamics: from soil to plant. American Society of Plant Biologists, Rockville

Open Access This chapter is licensed under the terms of the Creative Commons Attribution 4.0 International License (http://creativecommons.org/licenses/by/4.0/), which permits use, sharing, adaptation, distribution and reproduction in any medium or format, as long as you give appropriate credit to the original author(s) and the source, provide a link to the Creative Commons license and indicate if changes were made.

The images or other third party material in this chapter are included in the chapter's Creative Commons license, unless indicated otherwise in a credit line to the material. If material is not included in the chapter's Creative Commons license and your intended use is not permitted by statutory regulation or exceeds the permitted use, you will need to obtain permission directly from the copyright holder. 